YEARBŌOK -
of ANTITRUST
and REGULATORY
STUDIES
www.yars.wz.uw.edu.pl

Peer-reviewed scientific periodical, focusing on legal and economic issues of antitrust and regulation. Creative Commons Attribution-No Derivative Works 3.0 Poland License.

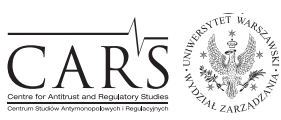

Centre for Antitrust and Regulatory Studies, University of Warsaw, Faculty of Management www.cars.wZ.uw.edu.pl

\title{
EU Competition Law Put to the Brexit Test: What Impact Might the Exit of the UK from the Union Have on the Enforcement of the Competition Rules?
}

\author{
by
}

Arianna Andreangeli*

\section{CONTENTS}

I. Introduction

II. Leaving the safe harbour of the Brussels Regulation: private enforcement in a post-Brexit world - is reviving old instruments a feasible option for multi-party, transnational competition claims?

III. Brexit and public competition enforcement: leaving the safe harbour of the ECN and sailing into uncertainty?

1. Out of the European Competition Network: the new reality of cooperation without EU membership

2. From partners... to what exactly? Forging a new relationship between the CMA and the (rest of) the ECN

IV. Brexit and competition enforcement in Europe: straining at the seams of EU law principles?

\section{Abstract}

This contribution examines some of the consequences of the UK's exit from the European Union for the enforcement of the competition rules. It reflects on the impact that Brexit is going to have on future transnational antitrust litigation in

* Senior lecturer in Competition law, Edinburgh Law School, University of Edinburgh. Heartfelt thanks are owed to Aiste Slezeviciute, PhD candidate at Edinburgh Law School, for the many discussions on these issues. An earlier version of this contribution was presented at the First Gaetano Filangieri Conference on Freedom of Commerce 'Recent developments in EU Competition Law', held at the University of Naples 'Federico II' on 8-9 May 2018. The author is grateful to all participants for their comments. The usual disclaimer applies. Article received: 4 May 2018; accepted: 31 May 2018. 
Britain and Europe. Thereafter it analyses the challenges that Brexit is likely to present for cooperation in public competition enforcement and suggests solutions for future development.

\section{Résumé}

Cet article examine les certaines conséquences de la sortie du Royaume-Uni de l'Union européenne sur l'application des règles de concurrence. Il se penche sur l'impact que Brexit va avoir sur les futurs litiges transnationaux en matière d'antitrust en Grande-Bretagne et en Europe. Puis, il analyse les défis que Brexit est susceptible de présenter pour la coopération dans l'application de la coopération publique et suggère des solutions pour le futur développement.

Key words: competition; litigation; Brussels Regulation; Brexit; cooperation

JEL: K21, K41

\section{Introduction}

Brexit represents an epochal change for both the United Kingdom and the European Union: the challenges that it brings to the UK are well known. How will the competences hitherto exercised by the Union be repatriated to London and, it is hoped, to the other nations of the UK, such as Scotland and Wales? How easy will it be for the British state to respond to the demands arising from the exercise of these powers? What will be the destiny of those areas of UK law that have so far developed in sync with EU law, such as competition law? In this particular area a number of further issues are going to arise both for the UK's competition authority and for the UK courts: as the Competition and Markets Authority (hereinafter; CMA) exits from the European Competition Network (hereinafter: ECN), and regains full competence to deal with mergers having an impact on UK markets, strains on its operational capacities will be inevitable. Furthermore, with the commitment expressed numerous times by many ministers to develop a new national industrial strategy, the perspective that the EU Commission will lose its state aid powers vis-à-vis UK financial measures raises concerns of new protectionism and of the emergence of national champions.

The UK courts will also be at the forefront of the need to respond to the challenges brought by Brexit in the exercise of their jurisdictional powers: so far Section 60 of the UK Competition Act 1998 has guaranteed that British antitrust rules will be applied in a way that mirrors the Court of Justice of the EU's interpretation of Articles 101 and 102 TFEU. It is true that the 
EU Withdrawal Bill, which is currently being scrutinised by the House of Lords, has indicated that the UK courts will have to take into account future EU case law. However, especially with the passage of years after the exit of the UK from the Union, it may become increasingly difficult to maintain 'synchronicity' between Luxembourg and the judiciary sitting in a former member of the EU. No longer will the UK courts be able to access the Court of Justice of the EU via the preliminary reference procedure. In addition, the decisions of the same Court will no longer be binding on British judges, or indeed the UK authorities generally - one of the 'red lines' enumerated by the UK Prime Minister in many of her speeches. ${ }^{1}$

But how is this sea change going to work in reality? It is in fact admittedly difficult to imagine that well-established case law, which has so far been grounded in the EU acquis, will be reversed so neatly at the end of the transition period. It is therefore suggested that the UK courts are unlikely, come the exit of the UK from the EU, to depart from their established acquis without a very compelling reason (e.g. Fletcher, 2017). It may therefore be expected that, as they seek to reconcile the demands of their new 'independence' from Luxembourg, the British courts will remain subject to the Court of Justice's 'soft power', for the benefit of legal certainty. And last, but by no means least, as the Brussels Regulation ${ }^{2}$ ceases to apply vis-à-vis the courts sitting in Britain and Northern Ireland, litigants in transnational disputes, as competition law cases often are, are going to face significant uncertainty as to the applicable law and to the identification of the court having jurisdiction to hear their claims.

Brexit, however, is not just going to have a massive impact on competition law and policy in the UK. Its effects are inevitably going to be felt in the Union and in the development of the interpretation and enforcement of the competition rules by the EU Commission, its ECN partners and ultimately the Court of Justice of the EU. The aim of this paper is to offer some reflections on some of these issues by taking a deliberately EU focused standpoint. Having regard to the private enforcement of the competition rules, it will explore the challenges arising from the future inapplicability of the Brussels regime for EU-wide rules on jurisdiction and parallel proceedings. Could Brexit de facto reverse the allegedly unstoppable path that had led to the Brussels acquis by 'reviving' earlier conventions and international agreements to which the UK had subscribed before 1972? Moreover, what consequences may the inapplicability

${ }^{1}$ See e.g. 'The Government's negotiating objectives for leaving the EU: PM Speech' (the 'Lancaster House speech'), 17 January 2017, available at: https://www.gov.uk/government/ speeches/the-governments-negotiating-objectives-for-exiting-the-eu-pm-speech.

2 Regulation of the European Parliament and the Council No 1215/2012 of 12 December 2012 on jurisdiction and the recognition of judgments in civil and commercial matters, [2012] OJ L351/1. 
of the Brussels Regulation vis-à-vis UK courts have in the field of competition law, where these courts had become a destination of choice for litigants?

Equally significant issues can arise in the area of public enforcement. With a 'hard' exit from the EU looming on the horizon, it is almost certain that the UK's CMA will no longer be part to the ECN, according to the EU's draft exit agreement with the UK. Yet, at the same time, the UK will be obliged to abide by the same principles of competition law that it subscribes to now, not only in the transitional period but also beyond March 2019. It is expected that the UK and the Union will negotiate cooperation arrangements akin to those in force between the EU and non-member states such as Switzerland, South Korea and Japan.

However, it is clear that they will be far less effective in terms of the depth of cooperation vis-à-vis the current ECN arrangements, thus potentially hindering the fact-finding and detection powers exercised by the Commission and the other ECN members in cases involving UK-based companies. So far, it looks as though the EU favours 'off the shelf' solutions to respond to the challenges presented by Brexit in a number of areas, and competition policy may make no exception to this approach. Yet, it is questionable whether the forms of cooperation that have so far characterised the relations of the EU with other jurisdictions may be appropriate, or indeed sufficient, to ensure the continuing detection of cartels that, despite political changes, are going to remain EU-wide. Could the UK's exit from the EU therefore warrant a rethink of this approach? And what consequences could this have on the status quo as regards the forms of cooperation within and outside the Union? Could we envisage a situation whereby the UK competition authority, as a former member, can cooperate more closely with the remaining ECN members than other non-member states?

\section{Leaving the safe harbours of the Brussels Regulation: private enforcement in a post-Brexit world - is reviving old instruments a feasible option for multi-party, transnational competition claims?}

We all know that one of the features of competition law disputes is to be multi-party and, in the EU context, to be also multi-national - impacting transnational trade, either actually or potentially, means that inevitably practices engaging the application of the EU antitrust rules are liable to fall within two or more different jurisdictions. Against this background it is beyond doubt that the availability of assured and reliable rules concerning the identification of a competent court is of capital importance for potential claimants. The Brussels Regulation has served precisely this purpose, namely to afford would-be 
plaintiffs the possibility to assess and identify the forum within which to sue in accordance with a set of clear criteria which tend to be non-exclusive. Thus, in a competition damages action, a plaintiff may decide to rely on the 'place of the domicile of the defendant' rule; however, if she happens to be a consumer and considers that evidence may be available in the jurisdiction in which she is based, she may decide instead to rely on the rule that affords jurisdiction over the same dispute to the court where she herself has her place of residence.

Leaving aside the debate on the desirability of competition among different fora, which the Regulation engenders, it is beyond doubt that its rules have ensured legal certainty for claimants and defendants as well as, thanks to the interpretation of its rules prevailing in England, allowing English courts to become courts of choice for many plaintiffs (see generally Danov, Becker and Beaumont, 2013). Brexit, however, stands to change all of this; no longer will plaintiffs seeking to launch a claim before the much trusted and efficient UK courts be able to rely on the safe harbours of the binding rules enshrined in Articles 4 and 7 of the Brussels Regulation. Nor will the judgments handed down by these courts be binding across the whole of the Union. Claimants lodging actions in other Member States are unlikely to rest easy as parallel actions in UK courts will not be ruled out; in addition, those victorious in other Member States will no longer be able to enforce their judgments quickly and easily in UK courts and vice versa (see Dickinson, 2016; Andreangeli, 2018, Ndolo and Liu, 2017).

It is acknowledged that these issues are encompassed in the agenda of the EU/UK negotiations and will therefore be given a resolution in that context. However, it is clear that the UK's exit from the Union will herald uncertainty as to the identification of the competent judge and the risk of parallel actions. In particular, it is worth reflecting on whether, once the UK leaves the 'safe space' of the Brussels regime, old international instruments of which the British state had been a signatory before its EU accession will 'revive' - could this 'resurrection' be compatible with current EU law principles? In addition, to what extent can the UK courts rely on domestic legal principles to decline jurisdiction before them that had been claimed in light of the Brussels Regulation? Although these courts will no longer be subjected to the principle of the supremacy of EU law, this question could be of capital importance for multi-party, multi-jurisdictional disputes where it may be more convenient for the parties, especially for the purpose of access to evidence and to justice, to petition British judges.

Before we examine the above issues, however, it is necessary to pause and consider why they are of particular importance not just for UK judges and lawyers, but also for EU competition law as a whole. As was anticipated, competition law disputes, especially those arising from the alleged infringement of Article 
101 TFEU, are in nature multi-party and multi-jurisdictional: unsurprisingly therefore, they are also subject to the application of the Union's conflicts of laws rules. Furthermore, it is well known that UK judges, and especially the English courts, have become a destination of choice for many litigants - they are perceived as competent, relatively quick (albeit not cheap by any means) and accessible, both in terms of standing and as regards the rules on evidence (see Lianos, Davies and Nebbia, 2015; Wurmnest, 2016; Danov, 2016).

The regime enshrined in the Brussels Regulation has been critical to the attainment of these outcomes, especially since the UK courts have been adopting a relatively extensive view of the jurisdictional rules. Cases like Provimi and Cooper Tyre have allowed non-UK plaintiffs to establish jurisdiction in the English courts on the sole ground that a member of the corporate group of one of the defendant companies had its domicile in England, and quite regardless of its direct involvement in the infringement. ${ }^{3}$ Although later case law, especially that handed down by the Competition Appeals Tribunal, aimed to lay down some boundaries to this rather sweeping reading of the standing rules, it is beyond doubt that the 'plaintiff-friendly approach' championed by these courts has promoted the standing of the UK as a good place to litigate competition claims. Where to, though, after Brexit?

It is sure that the UK's exit from the Union will lead to it 'regaining control' on yet another area of policy, albeit, it is forecast, at a significant cost to the legal services industry. However, it is unlikely to change the nature of competition cases, the resulting likelihood of multi-jurisdictional claims that may impact the UK jurisdiction and the preference for UK courts, at least for a time. This is why it is argued that whatever solution is agreed, it must not depart from the current EU acquis and, in particular, must continue to ensure clarity as to the competent court and avoid unnecessary burdens when it comes to executing judgments obtained elsewhere in Europe.

However, it is unclear whether these issues are going to be a priority in the current negotiations, hence the question of how can the gap left open by the intervening inapplicability of the Brussels regime be filled. As was anticipated above, it has been mooted whether international agreements which the UK and the EU had been parties to before 1972 can become applicable again. And what about those Conventions that had been signed by the Member States, but have now been subsumed into the current EU private international law framework? Moreover, could the parties to a competition case seek to resolve these problems themselves by agreeing ad hoc arbitration clauses, designed to overcome the uncertainty arising from the intervening inapplicability of the Brussels Regulation? Or is all this just a lot of 'scaremongering' since courts

3 Provimi Ltd v Aventis Animal Nutrition SA, [2003] EWHC 961 (Comm), para. 29, 30-34; also Cooper Tyre, [2009] EWHC (Comm) 269, para. 50; see also para. 55-56, 64. 
throughout Europe will continue to 'trust' each other, both in respect of the allocation of jurisdiction and the mutual recognition of judgments?

Coming to the first of these options, it may seem surprising but this has emerged in the debate as a feasible avenue to overcome the difficulties of a post-Brussels world. Among others, Dickinson argued in a recent article that come the exit from the Union, the UK would likely 'revert' to being bound, as a 'stand-alone' contracting state, to observe conventions such as, among others, the Lugano Convention concluded in 2007 that concerns jurisdiction, recognition and enforcement of judgments, as well as the 1980 Rome Convention or even the 1968 Brussels Convention (Dickinson, 2016).

It was suggested, in particular, that the 1980 Rome Convention could be a 'good candidate' for testing this possibility, since it had been 'open for signature by parties who (at that time) were members of the EEC', as was the UK (Dickinson, 2016). Moreover, it was emphasised that the Convention remains in force to the extent that it binds also, inter alia, 'overseas territories to which the EU' would not extend. Perhaps more importantly, its application to a non-EU member state would not be affected by the fact that it was 'replaced by the Rome I Regulation' for EU member states (Dickinson, 2016). On a similar vein, it has also been suggested that the 1968 Brussels Convention might again become applicable, since accession to it on the part of the UK was contingent upon EEC membership. It was also highlighted that the Convention itself has remained applicable to 'relations with the territories of the member states to which (...) the EU Treaties' do not apply (Dickinson, 2016).

There are, however, a number of objections to this scenario. It could be doubted in fact that the Court of Justice would allow these instruments to 'revive' their effects vis-à-vis the United Kingdom. On this point, it should be remembered that the Court identified in the West Tankers case 'the unification of the rules of conflict of jurisdiction in civil and commercial matters and the free movement of decisions in those matters' as the overriding objectives of the Brussels Regulation. ${ }^{4}$ Thus, the position of the Court could be interpreted as suggesting that the process leading to the enactment of the Regulation, which is aimed at ensuring the good functioning of the single market through establishing common, clear jurisdiction rules and allowing the 'free movement of judgments', is irreversible in nature (Andreangeli, 2017). On this basis, it would accordingly be difficult to conclude that these 'old' international instruments could be in any way 'revived' vis-à-vis the UK. To hold otherwise would, in fact, run counter to the principle of effectiveness of EU law, and therefore create tension between, on the one hand, reasons of practicality in the resolution of multi-party and multi-jurisdictional cases,

\footnotetext{
${ }^{4}$ Case C-185/07, Allianz and another v West Tankers, EU: C: 2009: 69, para. 24.
} 
such as competition claims, and, on the other hand, one of the central tenets of Union law (Dickinson, 2016; Andreangeli, 2017).

Could the parties to an agreement, then, seek to minimise this uncertainty by signing 'choice of court' clauses designed to bring competition claims arising from, for instance, cross-jurisdiction joint venture agreements or distribution arrangements? It is well-known that these clauses have long been regarded by the Court of Justice as inimical to the key principles and objectives of the Brussels Regulation. In the aforementioned West Tankers preliminary ruling, the Court expressed the view that a court could not be prevented from ruling on its own jurisdiction, in accordance with the Brussels Regulation, by means of either an arbitration agreement or an injunction issued by another court on the basis of such an agreement. ${ }^{5}$ The Court was very clear that no court could determine the scope of the jurisdiction of another court because to hold otherwise would have undermined both the full effect of the Regulation and the 'trust (...) that the Member States accord to one another's legal systems and judicial institutions (...)'.6

Come Brexit, however, West Tankers will no longer be applicable to UK courts, which could therefore be able, at least in principle, to issue anti-suit injunctions in competition claims. However, it is not at all clear whether these injunctions will be upheld by a court of an EU member state for the latter would still be bound to follow the West Tankers dictum (Ndolo and Liu, 2017). To overcome this difficulty, it has therefore been suggested for, after exit, the UK to join the 2005 Hague Convention on choice of court, which itself allows the enforcement of choice-of-court agreements and to which any state can accede (Ruhl, 2018). It is acknowledged that this approach, to the extent that it relies on the will of the parties to remedy the uncertainty arising from a 'hard Brexit', and from an at least momentary lack of an ad hoc agreement, could go some way toward protecting the jurisdiction of a UK court in a competition case. Nonetheless, it is well known that the Hague Convention presents a number of structural limits, such as its strictly defined scope and the fact that so far it has not attracted the support that the EU had hoped for at the time of its negotiation. (Ruhl, 2018).

Can the mutual trust that the courts of the EU member states have developed over the years come to the aid of competition litigants wishing to lodge their claim 'safely' in the English courts or the Competition Appeals Tribunal? It has been argued that national courts are likely to recognise the jurisdiction of UK courts on the basis of the rules on 'international lis pendens', enshrined in Part 4 of the Brussels Regulation (Nyombi and Dickson, 2017). Admittedly, this approach would address the risks of uncertainty for litigants

\footnotetext{
5 West Tankers, cit. (fn. 4), para. 29.

${ }^{6}$ Id., para. 30.
} 
as well as remain consistent with the EU acquis. However, what remains unclear is whether domestic law in force in the UK, and in particular the English rule of forum non conveniens, may become applicable once again, thus leading to outcomes that are once again difficult to reconcile with the Brussels regime. (Nyombi and Dickson, 2017; also Allen and Overy, brief, 2016). It was mentioned earlier that Brexit is likely to allow the UK to 'regain control' over the jurisdiction of these courts in an area, such as antitrust law, where the latter had been interpreted in a generous and rather plaintiff-friendly manner. It could thus be argued, not without merit, that the doctrine of forum non conveniens, which has been so far outlawed in cases falling within the scope of the Brussels Regulation, ${ }^{7}$ could be consistent with this objective, since it would allow English courts to decline the power to adjudicate on cases that can be justly tried elsewhere and quite regardless of the will of the parties (inter alia Andreangeli, 2018). Against this background, it may legitimately be doubted whether the mutual trust among national courts, that has so far accompanied EU membership, could be taken for granted in any way in a post-Brexit world without going as far as questioning, if not as putting under clear strain, those principles that have guided the allocation of jurisdiction in multi-party and multi-national competition claims (Merret, 2018).

In light of the above analysis, it may be concluded that the adjudication of multi-jurisdictional, multi-party disputes, such as competition cases, in a post-Brexit era is likely to create significant tension in the framework of principles that have so far guided the allocation of jurisdiction and the mutual recognition of judgments in the EU. It is acknowledged that many of these questions are likely to be subjected to negotiations, and will hopefully be settled as part of the exit deal between the UK and the EU. However, it is argued that until such time as this deal takes shape, litigants will be faced with great uncertainty and, more generally, a lot of the 'established wisdom' surrounding this area will be put to the test.

\section{Brexit and public competition enforcement: leaving the safe harbour of the ECN and sailing into uncertainty?}

\section{Out of the European Competition Network - the new reality of cooperation without EU membership}

The previous section highlighted some of the consequences of Brexit and argued that the exit from the Union will have significant consequence not

\footnotetext{
7 See e.g. case C-68/93, Shevill, EU: C: 1995: 61, para. 35-37.
} 
only for the UK; it is also going to have an as yet unknown impact on key EU law principles, that have so far been fundamental for the effective private enforcement of the competition rules, namely those key tenets of EU conflicts of laws that have allowed antitrust litigation to flourish in Britain. The public enforcement of the competition rules is equally going to be no stranger to similar tensions. So far Section 60 of the Competition Act 1998, in accordance with principles of effectiveness and supremacy of EU law, has ensured that the rules governing the investigating powers enjoyed by the CMA are extended to give effect in the UK to decisions adopted by the EU Commission in the detection of infringements which have prima facie occurred within the UK jurisdiction, thus being critical to British competition agency's fulfilment of its duties of cooperation within the European Competition Network.

Brexit is going to have a significant impact on this status quo. No longer will the infringement decisions adopted by the EU Commission be legally binding within the UK jurisdiction. In addition, and perhaps more critically, the CMA will no longer be subjected to its obligations and endowed with its powers as a member of the European Competition Network (see Cengiz, 2012). In this specific respect, it is clear that the deep cooperation existing among the National Competition Authorities (hereinafter; NCAs) in the EU and between the NCAs and the Commission have allowed each member of the ECN to investigate far more efficiently prima facie infringements having an impact on interstate trade. The CMA itself recognises the importance of the Network and of the duties and powers of cooperation bestowed upon it by Council Regulation No 1/2003 for the fulfilment of its statutory duties. ${ }^{8}$

This all, however, stands to change dramatically since, according to the Draft Withdrawal agreement formulated by the EU, the British competition agency will no longer be a member of the ECN, thereby losing a host of investigative powers such as: the power of exchange and use in evidence documents gathered in the course of competition investigations and the power to ask other authorities to carry out inspections on its behalf. It is expected that this, among other issues, will be settled in the course of the exit negotiations. However, it is legitimate to doubt that whatever cooperation the UK secures vis-à-vis its erstwhile ECN partners, this cooperation will be as deep as the one that is available now to the CMA as a member of the Network. Additionally, addressing this issue as part of the exit negotiations is likely to be even more urgent since the EU aims to move to even greater cooperation among the NCAs and to reinforcing the authorities' investigating and sanctioning powers

8 See e.g. speech given by the CMA's Chief Executive, Dr Andrea Coscelli, on 4 February 2017, available at: https:/www.gov.uk/government/speeches/andrea-coscelli-on-the-cmas-roleas-the-uk-exits-the-european-union (last accessed on 31 July 2018). 
through the EU Commission's 'ECN+' Directive proposal. ${ }^{9}$ Arguably, this is not going to be just a problem for the UK: it is in fact submitted that Brexit is unlikely to change the integrated nature of the EU's economy, within which the UK is a very significant player. Nor is it going to mean that transnational cartels involving UK based firms will be less likely in the future.

Against this background, it is argued that the circumstance that EU competition law may be applicable in an extra-territorial manner is indeed a tangible possibility. As is well known, the Court of Justice has accepted that Articles 101 and 102 TFEU and the EU Merger Regulation can apply to practices involving companies based outside the Union. Just to name one notorious judgment - in the Dyestuffs appeal decision the Court held that even though the appellant company had at the time no seat within the common market, the Commission could still impose a fine on it with respect to an infringement committed by a subsidiary company, which the appellant - a company having its seat outside the EEC at the time - controlled totally on the ground that the breach had produced its effects within the Common Market. ${ }^{10}$ In other words, it is the place in which an agreement or other anti-competitive practice is implemented that matters for the purpose of triggering the jurisdiction of EU law, as well as the attending power of the EU Commission or of any other member of the ECN to investigate and sanction the infringers. ${ }^{11}$

In light of the above, it may be concluded that addressing the 'vacuum' arising from the CMA no longer being a member of the ECN is a key imperative for the EU just as much as for the UK. But how could this objective be achieved? Could proposing solutions that are 'off-the-shelf' be the only way of doing so? Or should the negotiating parties instead prefer a more creative approach to these issues, one that perhaps takes into account the fact that up to the moment of exit the UK has been compliant with the Union acquis? These questions will be addressed in the next subsection.

\section{From partners to... what exactly? Forging a new relation between the CMA and the (rest of the) ECN}

The previous subsection highlighted some of the immediate consequences of Brexit for the position of the CMA vis-à-vis the European Competition

9 Proposal for a Directive of the European Parliament and the Council to empower the competition authorities of the member states to be more effective enforcers and to ensure the proper functioning of the internal market, 22 March 2017 COM(2017) 142 final, available at: http://ec.europa.eu/competition/antitrust/proposed_directive_en.pdf.

10 Case 45/69, ICI v Commission, EU: C: $1970: \overline{3}$, para. 128; see also paras. 130-136 and 141.

11 See also, inter alia, case C-89/85, Re: Wood Pulp, EU:C:1998:447, para. 16-18. 
Network. It was argued that, as the UK's exit from the EU is not going to affect the possibility for competition infringements to be cross-border, securing strong cooperation links between the UK and the rest of the Union is a priority not only for Britain but also for the EU as a whole.

The purpose of this subsection will be to consider the alternatives to the current model that may be deployed in a post-Brexit world to ensure the continued, seamless and Europe-wide application of the competition rules on the part of the CMA and ECN's member agencies. It is well-known that in order to investigate and detect prima facie competition infringements, whose impact spans jurisdictions within and outside the EU, the Union has negotiated and concluded a number of cooperation arrangements with key partners. Such arrangements can, however, have different characteristics and focus on different elements of the investigating and sanctioning procedures; cooperation may be agreed to take place at the early stages of a case by, for instance, imposing on the parties an obligation to communicate to each other the start of a new investigation. Or it may entail the power and the corresponding duty to exchange information and evidence (e.g. Demedst, 2012). In this specific context, this form of cooperation can once again be more or less extensive.

Having regard especially to antitrust cooperation in which the EU engages, existing instruments can be categorised in different ways. In the so-called 'first generation agreements', the EU and its major trading partners, such as the US (1991), Canada (1993) and South Korea (2009), have undertaken to have a shared framework for the exchange of basic information concerning ongoing investigations. Within these frameworks, however, it is not possible to exchange information and documents gathered in the course of an individual investigation unless the parties to the investigation agree to such exchange (Demedst, 2012). In practice, therefore, only non-confidential information can be transmitted to another jurisdiction; the parties to first generation agreements are under no obligation to disregard their own domestic law, for instance by exchanging information that would have to remain confidential according to national rules (Demedst, 2012).

Upon perceiving these limitations, the EU Commission, taking stock also of the commitments made in 1998 by OECD members in a Recommendation concerning effective action against hardcore cartels ${ }^{12}$, took steps toward the negotiation of agreements entailing greater cooperation. 'Second generation agreements', therefore, allow the parties to cooperate more deeply among each other, by not only undertaking to communicate to each other information about new or ongoing cases, but also by being able to exchange evidence

12 (1998), available at: http://www.oecd.org/daf/competition/recommendationconcerning effectiveactionagainsthardcorecartels.htm. 
gathered in the course of investigations, albeit within certain limits (Demedst, 2012). So far, however, the EU has concluded only one second generation agreement with Switzerland. ${ }^{13}$ Incidentally, while in 1994 the US had put in place internal legislation aimed at allowing for similar instruments to be negotiated and concluded, no such agreement has been forthcoming (e.g. Newman and Delgado Echevarria, 2004). The EU/Swiss cooperation framework enables the parties to reciprocally exchange information gathered as evidence in competition investigations, albeit within strict limitations aimed at the protection of confidentiality; perhaps most importantly, the information exchanged under the agreement cannot be used in order to impose sanctions on individuals (Demedst, 2012).

Antitrust cooperation has also been possible thanks to other instruments; comprehensive mutual legal assistance treaties, for instance, have provided competition authorities with a tool to obtain assistance in competition cases, for instance for the purpose of obtaining evidence located in a different jurisdiction (Martinszyin, 2015; Joshua, 2008). Their use in antitrust investigations is however limited: unlike in many domestic jurisdictions, there is no EU-wide criminal offence for cartel behaviours, thus precluding the application of treaties aimed at ensuring cooperation with respect of criminal matters (Joshua, 2008). In addition, the forms through which this cooperation takes place are often cumbersome, since they usually involve the use of diplomatic channels or the involvement of judicial authorities (Joshua, 2008).

Competition provisions have also been included in free trade agreements (hereinafter; FTAs): thus, in the EU/South Korea free trade agreement, concluded in 2010, the parties reiterated their commitment to the existing competition cooperation agreement, concluded in 2009 and aimed at ensuring mutual cooperation, coordination and consultation as well as the exchange of non-confidential information. The FTA provided for an additional commitment of reciprocal consultation in matters of competition policy and to the exchange of non-confidential documents in those circumstances that were not covered by the 2009 agreement (Demedst, 2012). Similarly, the 2011 Agreement between the EU and Columbia and Peru contains a number of provisions designed to facilitate cooperation and coordination in competition cases, the making of representations in cases of mutual concern and a limited exchange of information between jurisdictions (subject to the limits enshrined in domestic law as regards confidentiality) (Demedst, 2012).

It is added that the recent Canada-EU Trade Agreement (hereinafter; CETA), currently subject to ratification by national parliaments, reiterates

13 Agreement between the European Union and the Swiss Confederation concerning cooperation on the application of their competition laws, (2014) OJ L347/3; EU Commission press release, http://europa.eu/rapid/press-release_IP-14-2245_en.htm. 
the importance of inter-agency cooperation and for that purpose confirms that such cooperation will continue to take place in the forms established by the 1999 Canada/EU Competition Cooperation agreement; ${ }^{14}$ this agreement ${ }^{15}$ requires each party to notify the other party of the initiation of new cartel and abuse of dominance cases that may affect their interests. ${ }^{16}$ The Agreement also provides for a framework for exchange of information and legal assistance as well as for the mutual consultation as regards matters of mutual interest. These powers are, however, subject to significant limits: in accordance with the principle of comity, information can only be exchanged if it is in the interest of both parties and allowed by the respective domestic laws. ${ }^{17}$ Moreover, Article $\mathrm{X}(2)$ commits both parties to maintaining the confidentiality of any such information and imposes on each party the duty to oppose disclosure sought by a third party.

'Soft' forms of cooperation have also had a place in the EU's policy aimed at securing greater coordination and assistance from competition agencies outside its jurisdiction. Memoranda of understanding, for instance, have been negotiated with several countries: unlike treaties, these are merely administrative arrangements that, in accordance with principles of negative and positive comity, deal with issues of 'cooperation and coordination, assistance (...) and avoidance of conflict (...)'; they also lay out a basic mechanism for communication and rules on the confidentiality of the information reciprocally transmitted in the course of their application (Demedst, 2012). They are, however, entirely voluntary: thus, despite constituting flexile tools for the management of inter-agency cooperation, they do not create any obligations under international law, or indeed set aside any obligation enshrined in domestic law, most importantly those obligations concerning the confidentiality of information (Demesdt, 2012).

In light of the forgoing summary, it must be acknowledged that the ECN is not the only framework within which the Commission cooperates with competition agencies in other jurisdictions for the purpose of an effective detection and sanctioning of antitrust infringements. However, it certainly allows for very effective, almost seamless cooperation, as well as ensures that multiple proceedings concerning the same prima facie breach can be avoided (Cengiz, 2012). At its heart is the timely notification of new cases, avoidance of parallel actions and, at the same time, preference for joint actions should

14 See Article 17.2, Comprehensive Economic and Trade Agreement between Canada and the EU, (2017) OJ L11/23.

15 Agreement between the European Communities and the Government of Canada regarding the application of their competition laws, (1999) OJ L175/50.

16 Article II.

17 Article VII. 
more than one authority be best placed to deal with a particular investigation; perhaps its most important feature is the possibility to both exchange and use in evidence material gathered in another jurisdiction and to carry out fact-finding measures on behalf of another authority. ${ }^{18}$ This is to take place in an informal, relatively flexible forum, where, on the one hand, there is no 'clearing house' as regards case allocation but, on the other hand, extensive cooperation takes place, including the exchange and use as evidence of information gathered by other NCAs and the ability to request a partner agency to act as an investigating authority on behalf of the requesting party (e.g. Hjemtveldt, 2017).

Can other 'off-the-shelf' instruments be as effective as mechanisms for coordination and cooperation as the ECN? It is doubtful that 'first generation agreements' or competition cooperation provisions contained in FTAs may prove as effective; it is in fact submitted that under these arrangements the CMA and the EU Commission, for instance, would not be able to reciprocally exchange confidential information or indeed to carry out investigative measures on their reciprocal behalf with the same seamlessness as is the case under the current ECN structure (Demedst, 2012). As highlighted above when briefly discussing the Competition Chapter of the CETA, any cooperation between the EU Commission and a third country competition agency is very likely to be limited by the application of the principles of positive and negative comity, as well as by the continuing commitment to respect the confidentiality of the investigated parties.

It is equally difficult to imagine that mutual legal assistance treaties (MLATs) may replace the existing Network, not least because cartel behaviour is not criminalised in all of the Member States as well as in the EU, with the consequence that, the 'double criminality' requirement not being met, these treaties would not be applicable (Burnside and Crossley, 2005; Joshua, Camesasca and Jung, 2008). As for memoranda of understanding (MoUs), once again, limits concerning the protection of the confidentiality of information and the entirely voluntary nature of these arrangements are not going to be a suitable replacement as a means of regulating the future UK/EU relationship in the context of competition enforcement (Slot, 2015).

But what about second generation agreements? As was discussed earlier, the EU has so far negotiated one such agreement with Switzerland. This type of arrangement provides for deeper cooperation, for example by allowing the parties to reciprocally exchange information that can be used as evidence in circumstances equivalent to those listed in Article 12 of Council Regulation No 1/2003; the existing agreement also allows for reciprocal cooperation in the

18 See EU Commission, Notice on cooperation within the network of competition authorities ('the Network Notice'), (2004) OJ C101/43, especially para. 1 and 3. 
taking of evidence, again within the limits enshrined in the applicable national law (Slot, 2015). It could be suggested, not without merit, that an arrangement akin to the EU/Swiss agreement could replicate the key features of the ECN, by encompassing comparable cooperation and coordination prerogatives and, therefore, to ensure both the exchange of evidence and the carrying out of investigative measures by proxy.

On a closer look, however, this is not so straightforward. A new agreement of this kind is going to require time to negotiate and conclude: by way of example, it took the EU and the Swiss authorities nearly 3 years to negotiate the current arrangement, between 2011 and 2013, and the latter entered into force in 2014. Thus, even taking into account the transition period, time seems to be at least tight for the UK and the EU Commission to engage in talks aimed at undertaking similar cooperation rights and obligations (Wagner von Papp, 2017). It is also not entirely clear whether a second-generation agreement could, in practice, secure all the benefits of the ECN: having regard, for instance, to the exchange of information and, in this context, to the protection of lawyer-client confidentiality, it bears reminding that UK lawyers will no longer benefit from the current EU safeguards, which are linked to the legal adviser being authorised to practice in one of the Union's member states. ${ }^{19}$ Thus, it could be argued that even under a second generation agreement, a UK-regulated lawyer would not be able to claim privilege against a request to disclose documents issued by the NCA of one of the EU member states. In addition, the consent of the parties to the case in question to the exchange of information may still be necessary: for instance, the EU/Swiss agreement requires such consent when evidence originating from a lawyer is required for transmission from Switzerland. The same applies vis-à-vis evidence provided as part of a leniency application or settlement process. ${ }^{20}$

Against this background, it is argued that in practice jeopardising cooperation in competition enforcement with one of the key NCAs in Europe will be an almost inevitable consequence of a hard Brexit. Is the negotiation of a new agreement, either as stand-alone or as part of the main treaty setting out the new trading relations between the EU and the UK the only way of creating a new framework for cooperation in this field? On a first look, a resounding 'yes' may seem the only answer. The UK will be just like any other third state and will be treated as such. On reflection, however, the reply to this question is not so simple: it should be remembered that come its exit, the UK will not just be 'another third state'. It will be a former member state, and as such its

19 See case C-550/07 P, AKZO Nobel and others v Commission, EU: C: 2010: 512, para. $40 \mathrm{ff}$.

${ }^{20}$ See Agreement between the European Union and the Swiss Confederation, cit. (fn. 12), especially Article 7(5) and (6). 
internal laws will be compliant with the EU acquis. In addition, bearing in mind the text of the EU Withdrawal Bill ${ }^{21}$ and the stipulations made by the EU in its Draft agreement ${ }^{22}$, it is legitimate to expect that such consistency will remain for some time to come for a number of reasons. First of all, the UK courts will endeavour to take into account the judgments of the Court of Justice of the EU in cases where the application of 'repatriated' EU law is at stake. ${ }^{23}$ Secondly, the UK will continue to be a party to international cooperation and consultation frameworks such as the International Competition Network and the OECD. Although it is acknowledged that these fora only provide space for 'soft' forms of collaboration, it is likely that, to the extent that they provide space for discussion of issues of mutual concern and for the exchange of best practices, they will help maintain convergence between the CMA and its erstwhile ECN patterns.

On this basis, would it perhaps be too bold to suggest that the negotiating parties could go beyond the 'off-the-shelf' solution of a 'second generation' cooperation agreement and undertake to maintain the status quo as regards the position and the relations existing between the CMA and the rest of the ECN? It is suggested that this is not a moot question, nor just a flippant proposal. It should be recalled that at the root of the tight relationship existing among the members of the ECN are a number of tenets, one of which is the recognition that the rights of defence enjoyed by the parties affected by competition investigation in each member state must be considered 'sufficiently equivalent'. ${ }^{24}$ It is further argued that Brexit will not mean the abrogation of the UK Competition Act 1998, or indeed of the UK's domestic legislation safeguarding fundamental rights: if anything, the whole purpose of the UK Parliament enacting legislation designed to incorporate EU law into national law is to avoid the 'cliff-edge', namely the creation of any normative vacuum in areas where the EU retains competence until the UK exits the Union. ${ }^{25}$

21 See e.g. Article 6(2), Draft EU (Withdrawal) Bill, available at: https://publications. parliament.uk/pa/bills/lbill/2017-2019/0079/18079.pdf, especially para. 2 and $19 \mathrm{ff}$.

22 See e.g., mutatis mutandis, Article 126 of the EU Draft Withdrawal Agreement, available at: https://ec.europa.eu/commission/publications/draft-withdrawal-agreement-withdrawalunited-kingdom-great-britain-and-northern-ireland-european-union-and-european-atomicenergy-community_en.

23 Ibid.

24 See Recital 16, Preamble to Council Regulation No 1/2003, (2004) OJ L1/1.

25 See inter alia, Rt Hon David Davis MP, Speech given in Vienna on 20 February 2018, available at: https:/www.gov.uk/government/news/david-davis-foundations-of-the-futureeconomic-partnership-speech; also Explanatory Notes to the Bill, available at: https:// publications.parliament.uk/pa/bills/lbill/2017-2019/0079/18079en.pdf. 
Against this background, it would be difficult to conclude that come the exit of Britain from the EU this equivalence will no longer exist. Accordingly, it is submitted that the CMA could still be considered a 'trusted member' of the ECN and, consequently, could be entitled to enjoy similar prerogatives as it is entitled to under Council Regulation No 1/2003 as the latter stands at the time in which the UK's exit takes its full effect - namely, at the end of the transition period. The continuation of the existing relationship could be enshrined, perhaps, into a chapter of the future Withdrawal agreement and further complemented by a Memorandum of Understanding designing new practical arrangements underscoring the future $\mathrm{CMA} / \mathrm{ECN}$ cooperation.

It is recognised that this is a very bold suggestion; it is also acknowledged that just as there are a number of normative justifications in support of it, so there are equally meritorious objections to it. As a result of Brexit, the UK will no longer be bound to the principle of supremacy of EU $\operatorname{law}^{26}$ and, perhaps more importantly, the Court of Justice of the EU will no longer have jurisdiction in the UK, especially via the preliminary reference procedure. In addition, it is unclear whether, should the proposed Directive aimed at enhancing the powers currently enjoyed by the ECN members be adopted and later transposed, the CMA may come to enjoy more extensive prerogatives than those enjoyed by the ECN members beyond the point of exit. Nonetheless, it is argued that, if the concern for both the British authorities and the EU negotiators is to avoid a 'cliff-edge' in the area of antitrust cooperation and to maintain the existing status quo, a modicum of pragmatism and trust, the latter supported by an expectation of continuing mutual consistency when it comes to, inter alia, the protection of the rights of defence of investigated parties, may be on order.

In conclusion, it cannot be denied that Brexit is going to be a challenging transition not just for the UK but also for the EU. While at first glance adopting 'off-the-shelf' options seems to be inevitable, such as secondgeneration cooperation agreements, a closer look at the practical consequence of Britain's exit from the Union could provide support for a tailor-made response to the question of how the relationship of the CMA with its erstwhile ECN partners should be fashioned and, in that context, for adopting arrangements that are as close as possible to existing forms and depth of cooperation. It is acknowledged that venturing down this road may put into question key principles of EU law, including the integrity of the jurisdiction of the Court of Justice. However, it is at least worth considering this option seriously, if the EU's commitment to fighting transnational cartels is to remain a real one in a post-Brexit Europe.

26 See Explanatory Notes, cit. (fn. 24), para. 2, 53. 


\section{Conclusions: Brexit and competition enforcement in Europe - straining at the seams of EU law principles?}

The exit of the UK from the EU has marked a seismic moment for the Union, first and foremost politically: even one of the drafters of the Treaty of Lisbon, Lord Kerr of Kinlochard, admitted some time ago that Article 50 had been designed while taking the view that no member state, not least the UK, would have wanted to leave the EU (Gray, 2017). Competition enforcement, whether public or private, is not going to be immune to the aftershocks of this change. As illustrated so far, avoiding the 'cliff-edge' is not just an imperative for Britain but also for the EU. At the same time, however, it has been shown that attaining this objective does not come without a cost. If on the one hand it may seem appealing to 'resurrect' old conventions, so that some degree of continuity with existing EU conflicts of laws rules can be maintained, on the other hand, going down this route may be very difficult to reconcile with the integrity and inner coherence of the Brussels Regulation regime.

Furthermore, it remains partly unclear how the UK courts will be able to balance the demands and opportunities of their newly acquired 'independence from Luxembourg' against the need to maintain legal certainty, an objective likely to be best served by abiding by the 'soft power' of the Court of Justice of the EU (see e.g., Boffey, 2017). While it may be expected that the British judiciary will continue to adhere to EU precedent for some time to come (e.g. Lock, 2017), it is undeniable that this outcome presents significant institutional and legitimacy challenges, such as those stemming from the absence of a British 'voice' on the EU bench.

Having regard to public enforcement and to the position of the CMA vis-à-vis the ECN, mutual trust and the expectation that the rights of defence will be protected to a standard that is equivalent in the UK to that of the EU could support adopting a solution to how to refashion the relationship between EU competition agencies, including the Commission, and their UK counterpart - a solution that is not 'off-the-shelf' and can more or less replicate existing arrangements. However, it is doubtful whether effectiveness in enforcement may be privileged at the expense, at least to a degree, of other key principles, including the integrity of the jurisdiction of the Court of Justice of the EU.

Two years from the Brexit referendum and no clarity exists on the future relationship of the UK and the Union. It is hoped that in the fog of uncertainty the negotiating sides do not lose sight of the importance of effective competition enforcement across Europe and, at the same time, of the need to avoid straining at the seams of a legal system where the commitment to well-functioning markets is so important. 


\section{Literature}

Allen and Overy (2016). Brexit - legal consequences for commercial parties, Paper 2, available at: http://www.allenovery.com/SiteCollectionDocuments/Brexit_-_Specialist_ Paper_No_2_-_English_jurisdiction_clauses_-_should_commercial_parties_change_ their_approach.PDF.

Andreangeli, A. (2018). The consequences of Brexit for competition litigation: an end to a success story? European Competition Law Review, 38(5), 226.

Boffey, T. (2017). UK fails to retain voice in European Court of Justice. The Guardian, 7/12/2017, available at: https:/www.theguardian.com/politics/2017/dec/07/brexit-uk-failsto-retain-voice-in-european-court-of-justice.

Burnside, H. and Crossley, A. (2005). Cooperation in competition: a new era. European Law Review, 30(2), 234.

Cengiz, F. (2010). Multilevel governance in competition policy: the European Competition Network. European Law Review 35(5), 360.Danov, M. Becker, F. and Beaumont, P. (2013). Cross-border EU competition law actions. Oxford and Portland, Oregon: Hart Publishing.

Danov, M. (2016). Private antitrust enforcement and private international law. In: C.I. Nagy (ed.). The procedural aspects of the application of competition law. Groningen: Europa Law Publishing.

Demedst, V. (2012). International cooperation and domestic antitrust law enforcement: different means, one goal? Competition Law Review, 8(3), 223.

Dickinson, A. (2016). The consequences of EU exit for private international law. Journal of Private International Law, 2, 195.

Gray, A. (2017). Interview of Lord Kerr. Politico.eu, 29/3/2017, available at: https://www. politico.eu/article/brexit-article-50-lord-kerr-john-kerr/.

Hjemtveldt, K. (2017). The decentralisation of enforcement of EU/EEA competition law. European Competition Law Review, 38(2), 60.

Joshua, J., Camesasca, P. and Jung, Y. (2008). Extradition and Mutual Legal Assistance Treaties: Cartel Enforcement Global Reach. Antitrust Law Journal 75(2), 353.

Lianos, I., Davies, P. and Nebbia, P. (2015). Damages actions for the infringement of the EU competition rules. Oxford: Oxford University Press.

Lock, T. (2017). Human rights in the UK after Brexit. Public Law Nov Suppl, 117.

Martyinszyn, M. (2015). Inter-agency evidence sharing in competition enforcement. International Journal of Evidence \& Proof, 19(1), 11.

Merret, S. (2018), The future enforcement of asymmetric jurisdiction agreements. International and Comparative Law Quarterly, 67(1), 37.

Ndolo, D. and Liu, M. (2017). Does the will of the parties supersede the sovereignty of the state? Anti-suit injunctions in the UK post-Brexit. Arbitration, 83(3), 254.

Newman, B. and Delgado Echevarria, M. (2004). Gaps and bridges: international cooperation. Global Competition Review, 7(9) (Suppl), 26.

Nyombi, C., and Dickson, M.O. (2017). Replacing lis pendens with forum non conveniens: a viable solution to tactical litigation in the EU? European Competition Law Review, 38(11), 491.

Ruhl, G. (2018). Judicial cooperation in civil and commercial matters after Brexit: which way forward? International and Comparative Law Quarterly, 67(1), 99. 
Slot, P.J. (2015). International competition law - bilateral treaties. European Competition Law Review, 36(9), 391.

Wagner-Von Papp, F. (2017). Blog post available at: https://www.law.ox.ac.uk/businesslaw-blog/blog/2017/08/competition-law-eu-free-trade-and-cooperation-agreements-andwhat-uk.

Wurmnest, W. (2016). International jurisdiction in competition damages cases under the Brussels Regulation. Common Market Law Review, 53(1), 225. 